\title{
UMA ANÁlise CRÍTICA SOBRE O ATIVISMO JUDICIAL A PARTIR DO JULGAMENTO DA ADPF N 347/DF
}

\section{A CRITICAL ANLYSIS ON JUDICIAL ACTIVISM FROM THE JUDGMENTE OF ADPF No 347/DF}

\section{Larissa Alvarenga Maringues de Aquino*}

\begin{abstract}
Resumo
O presente trabalho pretende analisar de maneira crítica o problema do ativismo judicial no Brasil, a partir do estudo do julgamento da ADPF 347/DF. O referido julgamento tratou da possibilidade ou não de utilização da chamada "teoria do estado de coisas inconstitucional", com o objetivo de declarar o estado de precariedade e falência do sistema prisional brasileiro. $\mathrm{O}$ que se espera com a leitura do presente trabalho é uma profunda reflexão se, em decorrência das omissões dos Poderes Legislativo e Executivo em questões relativas à efetivação de direitos e garantias fundamentais, poderia o Judiciário impor medidas para suprir essas lacunas deixadas por aqueles.
\end{abstract}

Palavras-chave: Ativismo judicial. Teoria do estado de coisas inconstitucional. Falência do sistema prisional. Omissões. Direitos fundamentais.

\begin{abstract}
This paper aims to analyze critically the problem of judicial activism in Brazil, from the study of the ADPF 347/DF judgment. This one discussed the possibility of using the theory of state's things unconstitucional, with de aim of declare the failure of the prision system. What is expected with the reading of this text is a deep reflection if, as a result of omissions of the legislative and executives power about fundamental rights, could the judiciary impose measures to fill the gaps left by those.
\end{abstract}

Keywords: Judicial activism. Theory of State's Things unconstitutional. Failure of the prison system. Omissions. Fundamental rights.

\section{INTRODUÇÃO}

\footnotetext{
Artigo submetido em 10 de julho de 2020 e aprovado em 17 de agosto de 2020 .

* Graduada em Direito pela Pontifícia Universidade Católica de Minas Gerais- Campus Coração Eucarístico. Especialista em Ciências Penais pela Pontifícia Universidade Católica de Minas Gerais- Campus Praça da Liberdade. Analista Jurídica do Ministério Público de São Paulo. Currículo Lattes: http://lattes.cnpq.br/2254544343479862. Email: larissaamaquino@ hotmail.com/larissaaquino@mpsp.mp.br
} 
Em meados de 2015, o STF passou a julgar a Arguição de Descumprimento de Preceito Fundamental $n^{\circ} 347 / D F$, a qual tratou do sistema carcerário brasileiro e que, inclusive, culminou na edição do Informativo 798. Nesta oportunidade, o Plenário do Supremo Tribunal Federal julgou uma medida cautelar, ajuizada pelo Partido Socialismo e Liberdade - PSOL, em que se discutia a possibilidade de se utilizar a tese do "estado de coisas inconstitucional" no que diz respeito à violação de direitos fundamentais dos apenados no Brasil.

A questão a ser levada a uma reflexão é justamente se, diante das omissões dos Poderes Executivo e Legislativo, que resultam na violação de direitos e garantias fundamentais, o poder Judiciário poderia impor medidas para suprir a ausência de políticas públicas e de políticas criminais adequadas à superação do chamado "estado de coisas inconstitucional". Tem-se que a atuação do Judiciário em questões políticas e sociais, isto é, em matérias que não são de sua competência direta, representa o fenômeno da Judicialização, o que pode influenciar no aumento do ativismo judicial.

Para que a presente pesquisa pudesse ser desenvolvida, a metodologia adotada consistiu em pesquisa bibliográfica, análise de dados e gráfico (infoPen), no estudo da jurisprudência e da doutrina brasileira e estrangeira, bem como na exposição de opiniões próprias sobre o tema.

Dessa forma, adotou-se um método hipotético-dedutivo (GUSTIN, 2013, p. 23), no sentido de reconhecer a existência do problema do ativismo judicial e refletir acerca da legitimidade das decisões proferidas pelo Poder Judiciário, principalmente no que diz respeito à efetivação de direito sociais. Ainda, é de se reconhecer a utilização do método dialético (2013, p. 24), uma vez que há a análise de entendimentos diversos quanto à atuação dos Magistrados em matérias que não são de sua competência.

Portanto, autores como STRECK (2015), diante da referida decisão do STF, passaram a discutir em seus textos os prós e contras quanto à utilização da tese do "estado de coisas inconstitucional" na realidade social e jurídica brasileira, razão pela qual seus textos foram valorizados na escrita do presente trabalho. Ademais, obras de autores estrangeiros foram utilizadas nesta escrita no que diz respeito ao ativismo judicial.

\section{UMA BREVE ANÁLISE DA TEORIA DO "ESTADO DE COISAS INCONSTITUCIONAL"}




\subsection{O "estado de coisas inconstitucional" e a Corte Constitucional Colombiana}

A tese do "estado de coisas inconstitucional" remonta às decisões proferidas pela Corte Constitucional da Colômbia, diante de generalizadas violações a direitos fundamentais da população carcerária. A Corte Colombiana se vale deste instituto quando reconhece uma violação exacerbada de direitos fundamentais de um conjunto significativo de pessoas.

Em relação à problemática situação do sistema penitenciário, o caso mais conhecido é o do processo T-153 do ano de 1998. Esse processo buscou, inicialmente, resolver os casos de insalubridade e violação de direitos fundamentais referentes às prisões de Bellavista (Medellín) e Modelo (Bogotá), porém, a decisão prolatada no dia 28/04/1998 acabou por considerar o sistema prisional de todo o país. No caso da Cadeia Distrital de Bellavista, localizada em Medellin, por exemplo, o estabelecimento foi criado para a capacidade de 1.500 detentos, porém, na data do ajuizamento do referido processo, já havia uma lotação de 4.969 presos. Na decisão T-153/1998, deixou-se bastante claro que a Corte Colombiana visava utilizar o instituto do "estado de coisas inconstitucional" como um remédio de combate às violações aos direitos fundamentais dos presos.

Esta Corporación ha hecho uso de la figura del estado de cosas inconstitucional con
el fin de buscar remedio a sit uaciones de vulneración de los derechos fundamentales
que tengan un carácter general - en tanto que afectan a multitud de personas -, y
cuyas causas sean de naturaleza estructural - es decir que, por lo regular, no se
originan de manera exclusiva en la autoridad demandada y, por lo tanto, su solución
exige la acción mancomunada de distintas entidades. En estas condiciones, la Corte
ha considerado que dado que miles de personas se encuentran en igual situación y
que si todas acudieran a la tutela podrían congestionar de manera innecesaria la
administración de justicia, lo más indicado es dictar órdenes a las instituciones
oficiales competentes con el fin de que pongan en acción sus facultades para
eliminar ese estado de cosas inconstitucional.

Na decisão proferida na Sentença T-153, a Corte Colombiana, resumidamente, declarou a necessidade de se elaborar um plano de construção e reformas nos estabelecimentos carcerários, bem como a imposição de medidas pelo Presidente do país para que os direitos dos apenados fossem assegurados.

CAMPOS (2015, p. 07) afirma que "presente violação massiva de direitos fundamentais decorrente de omissões caracterizadas como falhas estruturais, a Corte Constitucional colombiana declara a vigência de um estado de coisas inconstitucional". Portanto, a questão problemática acerca dos presídios colombianos se refere às chamadas "falhas estruturais" encontradas no sistema carcerário do país. Diante da gravidade dessas 
falhas estruturais, a Corte afirma ser legítima a sua intervenção para a implantação e execução de políticas públicas voltadas à solução do problema.

A pergunta que se faz diante dessa atuação atípica do Poder Judiciário em outro país é se a utilização da tese do "estado de coisas inconstitucional" seria bem aplicada no Brasil e quais seriam os riscos da implantação de tal teoria no ordenamento jurídico brasileiro.

\subsection{A utilização do Estado de Coisas Inconstitucional no Brasil}

\subsubsection{Levantamento de dados acerca da situação carcerária no Brasil}

O Sistema Nacional de Informação Penitenciária (InfoPen) procura coletar alguns dados sobre o sistema penitenciário no Brasil para divulgá-los a cada semestre no site do Ministério da Justiça. As informações coletadas e sistematizadas pelo instituto são fornecidas pelas próprias unidades prisionais ${ }^{1}$. A partir do gráfico abaixo, cuja fonte é o InfoPen, percebe-se um crescimento contínuo da população carcerária brasileira, o que reflete, diretamente, na questão da superlotação dos sistemas prisionais.

\section{Gráfico 1- População prisional brasileira em números absolutos entre 2005 e} 2012.

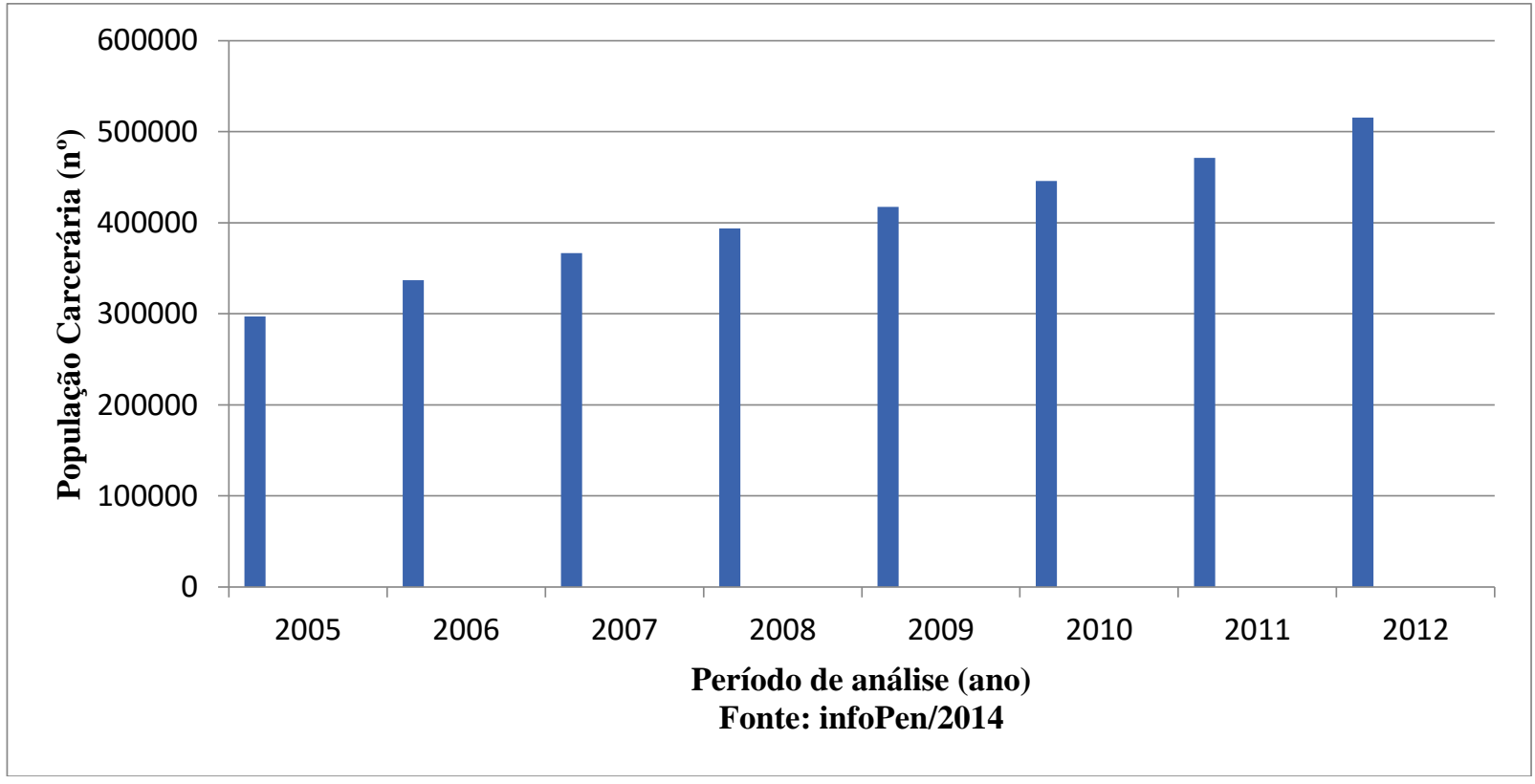

Tabela 1

\footnotetext{
${ }^{1}$ Disponível em: < www.pnud.org.br/arquivos/encarceramento_WEB.pdf>. Acesso em: 12 março 2016.
} 


\begin{tabular}{|l|l|}
\hline 2005 & 296.919 \\
\hline 2006 & 336.775 \\
\hline 2007 & 366.359 \\
\hline 2008 & 393.488 \\
\hline 2009 & 417.112 \\
\hline 2010 & 445.705 \\
\hline 2011 & 471.254 \\
\hline 2012 & 515.482 \\
\hline
\end{tabular}

(Tabela própria feita com as informações do gráfico acima)

No relatório divulgado pela InfoPen referente ao ano de 2014, constatou-se que a população carcerária brasileira subiu para 607.731. O número de vagas praticamente chega a 377 mil, contudo o déficit é de 231.062 vagas, ou seja, a taxa de ocupação médias dos estabelecimentos é de $161 \%$, o que demonstra que a superlotação dos presídios é um problema sério a ser enfrentado.

Convém ressaltar que o último dado apresentado no site do Infopen é o de que, até dezembro de 2019, a população prisional no Brasil é de 748.009, excluindo presos em delegacias. O total é de 755.274. Contudo, ainda que no mesmo site tenha se afirmado que “comparando os anos de 2018 e 2019, houve redução na taxa de crescimento populacional, que era de 2,97\% e passou para 1,49\%. Houve redução também de presos provisórios, de 35,06\% para 30,43\%" (DEPEN, 2019), é de conhecimento notório que a situação carcerária no país é de extrema gravidade.

No Brasil, a Lei 7210/84, a chamada Lei de Execução Penal (BRASIL, 2014) trouxe em seu artigo 41 uma série de direitos garantidos aos apenados, como as assistências materiais, à saúde, educacional, entre outros. Contudo, como se sabe, grande parte desses direitos não é garantido, diante da deficiência do sistema carcerário no Brasil, seja pela superpopulação carcerária, seja pelas condições insalubres de cumprimento de pena.

Art. 41 - Constituem direitos do preso:

I - alimentação suficiente e vestuário;

II - atribuição de trabalho e sua remuneração;

III - Previdência Social;

IV - constituição de pecúlio;

$\mathrm{V}$ - proporcionalidade na distribuição do tempo para o trabalho, o descanso e a recreação;

VI - exercício das atividades profissionais, intelectuais, artísticas e desportivas anteriores, desde que compatíveis com a execução da pena;

VII - assistência material, à saúde, jurídica, educacional, social e religiosa;

VIII - proteção contra qualquer forma de sensacionalismo;

IX - entrevista pessoal e reservada com o advogado;

$\mathrm{X}$ - visita do cônjuge, da companheira, de parentes e amigos em dias determinados; 
XI - chamamento nominal;

XII - igualdade de tratamento salvo quanto às exigências da individualização da pena;

XIII - audiência especial com o diretor do estabelecimento;

XIV - representação e petição a qualquer autoridade, em defesa de direito;

$\mathrm{XV}$ - contato com o mundo exterior por meio de correspondência escrita, da leitura e de outros meios de informação que não comprometam a moral e os bons costumes. XVI - atestado de pena a cumprir, emitido anualmente, sob pena da responsabilidade da autoridade judiciária competente. (Incluído pela Lei $\mathrm{n}^{\circ}$ 10.713, de 2003)

Parágrafo único. Os direitos previstos nos incisos V, X e XV poderão ser suspensos ou restringidos mediante ato motivado do diretor do estabelecimento.

A situação dos estabelecimentos penitenciários no Brasil é tão grave que a Corte Interamericana de Direitos Humanos já precisou intervir, obrigando o Estado Brasileiro a cumprir uma série de medidas a fim de estimular a erradicação das situações de risco, bem como adotar medidas que garantam a proteção à vida, à integridade física e moral dos apenados, entre outros direitos garantidos constitucionalmente. A Penitenciária de Urso Branco, em Rondônia, e o Complexo Penitenciário de Pedrinhas, na cidade de São Luís do Maranhão, foram alguns dos estabelecimentos prisionais analisados pela Corte Interamericana de Direitos Humanos, como pode ser ver abaixo.

\begin{abstract}
O Brasil tem estado na mira da Corte Interamericana nos últimos tempos. A situação dos presídios brasileiros já deu ensejo a várias medidas cautelares: no caso da Penitenciária de Urso Branco, em Rondônia, para evitar mais mortes de detentos, além das 37 já ocorridas; no caso da Penitenciária de Araraquara, ordenando a permissão de acesso a médicos, redução da população carcerária, permissão de visita de familiares dos presos, realização de investigação das denúncias existentes e tomada de medidas para preservar a vida e integridade dos detentos; no caso das crianças e adolescentes privados de liberdade na Fundação Casa do Tatuapé, em São Paulo; no caso do Complexo Penitenciário de Pedrinhas, na cidade de São Luís do Maranhão, pela situação de risco em que se encontram os presos, decorrente de vários atos de violência com violação do direito à vida e à integridade física, como visto em graves conflitos mais recentes; e, mais recentemente, no caso do Presídio Central de Porto Alegre, Rio Grande do Sul, com a edição da Resolução 14/2013 (Medida Cautelar 8-13).
\end{abstract}

Ademais, diante da calamidade do sistema penitenciário brasileiro, foi instaurada uma Comissão Parlamentar de Inquérito no ano de 2009 com o intuito de fazer levantamento de dados acerca dos problemas que afloram nos estabelecimentos prisionais do país. A CPI da Câmara dos Deputados revelou de forma clara a real situação dos presos no Brasil.

( ) Celas superlotadas ocasionam insalubridade, doenças, motins, rebeliões, mortes, degradação da pessoa humana. A CPI encontrou homens amontoados como lixo humano em celas cheias, se revezando para dormir, ou dormindo em cima do vaso sanitário. Em outros estabelecimentos, homens seminus gemendo diante da cela 
entupida. Em outros estabelecimentos, redes sobre redes em cima de camas. Mulheres com suas crianças recém-nascidas espremidas em celas sujas (...) Assim vivem os presos no Brasil. Assim são os estabelecimentos penais brasileiros na sua grande maioria. Assim é que as autoridades brasileiras cuidam dos seus presos pobres. E é assim que as autoridades colocam, todo santo dia, feras humanas jogadas na rua para conviver com a sociedade.

O que se pode ver é uma grande omissão por parte do Poder Público em garantir os direitos das pessoas presas, deixando-as à própria sorte. Certo é que o ambiente carcerário se apresenta como um local propício à proliferação de doenças, somado à falta de alimentação, ausência de assistências médicas, sociais, educacionais e materiais.

Contudo, esse cenário é totalmente incompatível com os direitos estabelecidos pela Constituição Republicana de 1988 (BRASIL, 2014), visto que esta consagra, entre outros, o direito à vida, bem como veda as sanções cruéis (art. 50, XLVII, “e”) e assegura aos presos o respeito à integridade física e moral (art. $5^{\circ}$, inciso XLIX, CR/88). Outrossim, a Magna Carta possui como um dos fundamentos republicanos a dignidade da pessoa humana. É importante salientar que o problema não é a ausência de normas que garantam esses direitos, mas sim a ineficiência por parte do Poder Público em efetivá-los.

Além da ausência de políticas públicas eficazes por parte do Poder Público, o Poder Legislativo também possui determinada parcela de responsabilidade diante deste quadro insustentável do sistema carcerário brasileiro. Isso porque os representantes no Congresso Nacional, influenciados pelo sentimento de insatisfação popular, bem como preocupados com o clamor público, adotam políticas criminais extremamente absurdas, como o agravamento das penas e a criação de novos crimes. Como bem exposto pelo PSOL na petição inicial da ADPF 347/DF:

O Poder Legislativo também tem - é certo - grave responsabilidade neste quadro. O legislador tem estabelecido políticas criminais absolutamente insensíveis ao drama carcerário brasileiro, que agravam a superlotação dos presídios e não geram a almejada segurança para a sociedade. Na esfera penal, a vontade de aplacar o legítimo sentimento social contrário à impunidade vem gerando o abuso, pelo Legislativo, da "legislação simbólica", expressão de um populismo penal que é uma das causas do dramático quadro prisional hoje desenhado no país (ADPF 347, p. 17)

Portanto, diante da omissão do Poder Público e da ineficiência e morosidade do processo legislativo, o Poder Judiciário acaba interferindo em questões que não são de sua competência direta, fenômeno este conhecido como "Judicialização", definido por BARROSO (2008, p. 03) como o fato de que 
(...) algumas questões de larga repercussão política ou social estão sendo decididas por órgãos do Poder Judiciário, e não pelas instâncias políticas tradicionais: o Congresso Nacional e o Poder Executivo - em cujo âmbito se encontram o Presidente da República, seus ministérios e a administração pública em geral. Como intuitivo, a judicialização envolve uma transferência de poder para juízes e tribunais, com alterações significativas na linguagem, na argumentação e no modo de participação da sociedade.

O referido fenômeno será estudado mais adiante. Por ora, tem-se a ideia de que o "estado de coisas inconstitucional" foi considerado um meio eficiente de garantia de direitos fundamentais pela Corte Colombiana. Resta efetuar uma análise acerca da utilização de tal teoria no cenário jurídico brasileiro e quais as consequências de sua utilização pelo Poder Judiciário como forma de sanar omissões deixadas pelo Poder Executivo e Poder Legislativo.

\subsection{2- A importação brasileira da tese do "estado de coisas inconstitucional"}

No Brasil, a tese do "estado de coisas inconstitucional" veio à tona com o julgamento da Cautelar na ADPF no 347 do Distrito Federal, de relatoria do Ministro Marco Aurélio². Trata-se, no caso, do ajuizamento de uma Ação de Descumprimento de Preceito Fundamental pelo Partido Socialismo e Liberdade (PSOL), que possuía como pedidos da medida cautelar, por exemplo, a necessidade de motivação pelo Magistrado acerca da decretação de prisão provisória, a obrigatoriedade da realização de audiência de custódia e o reconhecimento da precariedade do sistema carcerário brasileiro, no que diz respeito às condições de ressocialização do preso. Isso é o que se extrai do voto proferido pelo Ministro Edson Fachin no dia 03/09/2015:

Por ora, a análise se circunscreve ao pedido de medida cautelar, em que se requer ao Supremo Tribunal Federal que:

a) determine a todos os juízes e tribunais que, em caso de decretação de prisão provisória, motivem expressamente as razões que impossibilitam a aplicação das medidas cautelares alternativas à privação de liberdade, previstas no art. 319 do Código de Processo Penal;

b) reconheça a aplicabilidade imediata dos arts. 9.3 do Pacto dos Direitos Civis e Políticos e 7.5 da Convenção Interamericana de Direitos Humanos, determinando a todos os juízes e tribunais que passem a realizar audiências de custódia, no prazo máximo de 90 dias, de modo a viabilizar o comparecimento do preso perante a autoridade judiciária em até 24 horas contadas do momento da prisão;

\footnotetext{
${ }^{2}$ Importante ressaltar que a tese do "estado de coisas inconstitucional" já havia sido utilizada pelo STF na questão da modulação temporal da decisão que reconheceu a inconstitucionalidade da Emenda Constitucional no 62, referente ao pagamento de precatórios (Questão de Ordem nas ADIs 4.357 e 4.425, Rel. Mini. Luiz Fux, julg. 25/03/2015).
} 
c) determine aos juízes e tribunais brasileiros que passem a considerar fundamentadamente o dramático quadro fático do sistema penitenciário brasileiro no momento de concessão de cautelares penais, na aplicação da pena e durante o processo de execução penal;

d) reconheça que como a pena é sistematicamente cumprida em condições muito mais severas do que as admitidas pela ordem jurídica, a preservação, na medida do possível, da proporcionalidade e humanidade da sanção impõe que os juízes brasileiros apliquem, sempre que for viável, penas alternativas à prisão;

e) afirme que o juízo da execução penal tem o poder- dever de abrandar os requisitos temporais para a fruição de benefícios e direitos do preso, como a progressão de regime, o livramento condicional e a suspensão condicional da pena, quando se evidenciar que as condições de efetivo cumprimento da pena são significativamente mais severas do que as previstas na ordem jurídica e impostas pela sentença condenatória, visando assim a preservar, na medida do possível, a proporcionalidade e humanidade da sanção;

f) reconheça que o juízo da execução penal tem o poder-dever de abater tempo de prisão da pena a ser cumprida, quando se evidenciar que as condições do efetivo cumprimento da pena foram significativamente mais severas do que as previstas na ordem jurídica e impostas pela sentença condenatória, de forma a preservar, na medida do possível, a proporcionalidade e humanidade da sanção;

g) determine ao Conselho Nacional de Justiça que coordene um ou mais mutirões carcerários, de modo a viabilizar a pronta revisão de todos os processos de execução penal em curso no país que envolvam a aplicação de pena privativa de liberdade, visando a adequá-los às medidas "e" e "f" acima;

h) imponha o imediato descontingenciamento das verbas existentes no Fundo Penitenciário Nacional- FUNPEN, e vede à União Federal a realização de novos contingenciamentos, até que se reconheça a superação do estado de coisas inconstitucional do sistema prisional brasileiro.

O principal objetivo do ajuizamento da ADPF 347/DF, como pode se ver da petição inicial apresentada pelo PSOL, é o reconhecimento do chamado "estado de coisas inconstitucional" do sistema penitenciário brasileiro e, consequentemente, a adoção de medida capazes de sanar as violações aos preceitos fundamentais da Constituição Republicana.

Dessa forma, entende-se que a ADPF ora em análise trata, principalmente, do problema do (des)respeito aos direitos fundamentais da população encarcerada. Um processo de "ressocialização" em um ambiente completamente insalubre e desestruturado revela um sério desrespeito à dignidade da pessoa humana, bem como à integridade física e psicológica dos presos. A situação da população carcerária é bem descrita na petição inicial pelo Partido Socialismo e Liberdade:

As prisões brasileiras são, em geral, verdadeiros infernos dantescos, com celas superlotadas, imundas e insalubres, proliferação de doenças infectocontagiosas, comida intragável, temperaturas extremas, falta de água potável e de produtos higiênicos básicos. Homicídios, espancamentos, tortura e violência sexual contra os presos são frequentes, praticadas por outros detentos ou por agentes do próprio Estado. As instituições prisionais são comumente dominadas por facções criminosas, que impõem nas cadeias o seu reino de terror, às vezes com a cumplicidade do Poder Público. Faltam assistência judiciária adequada aos presos, 
acesso à educação, à saúde e ao trabalho. O controle estatal sobre o cumprimento das penas deixa muito a desejar e não é incomum que se encontrem, em mutirões carcerários, presos que já deveriam ter sido soltos há anos. Neste cenário revoltante, não é de se admirar a frequência com que ocorrem rebeliões e motins nas prisões, cada vez mais violentos (p. 02).

Outra medida concedida liminarmente pelo STF em setembro de 2015, no julgamento da Cautelar na ADPF 347/DF, diz respeito ao FUNPEN (Fundo Penitenciário Nacional). O Supremo determinou a proibição de contingenciamento dos valores disponíveis no referido fundo por parte do Poder Executivo, de forma que este deve liberar o saldo acumulado para que seja utilizado nas construções e reformas dos estabelecimentos penitenciários. Ademais, ordenou que o Executivo deveria se abster de realizar novos contingenciamentos.

\section{O PROBLEMA DO ATIVISMO JUDICIAL NO BRASIL}

\subsection{Uma análise acerca do ativismo judicial}

Certo é que após a redemocratização do país houve uma grande valorização do Poder Judiciário, que passou a intervir em grandes problemas enfrentados no Brasil, principalmente aqueles relacionados aos direitos sociais. Essa maior participação do Judiciário no cenário político e social passou a ser denominado "fenômeno da judicialização".

BARROSO (2008, p 02) explica que esse fenômeno "significa que algumas questões de larga repercussão política ou social estão sendo decididas por órgãos do Poder Judiciário, e não pelas instâncias políticas tradicionais: O Congresso Nacional e o Poder Executivo". O atual Ministro do Supremo Tribunal Federal ainda faz uma diferenciação importante entre a judicialização e o fenômeno do ativismo judicial, estes reiteradamente confundidos por muitas pessoas, com o intuito de explicar que o papel da referida Corte se encontra legitimado pelo ordenamento jurídico.

\footnotetext{
A judicialização, no contexto brasileiro, é um fato, uma circunstância que decorre do modelo constitucional que se adotou, e não um exercício deliberado de vontade política. Em todos os casos referidos acima, o Judiciário decidiu porque era o que lha cabia fazer, sem alternativa. Se uma norma constitucional permite que dela se deduza uma pretensão, subjetiva ou objetiva, ao juiz cabe dela conhecer, decidindo a matéria. Já o ativismo judicial é uma atitude, a escolha de um modo específico e proativo de interpretar a Constituição, expandindo o seu sentido e alcance. Normalmente ele se instala em situações de retração do Poder Legislativo, de um certo deslocamento entre a classe política e a sociedade civil, impedindo que as demandas sociais sejam atendidas de maneira efetiva (2008, p. 03).
} 
O professor BECATTINI (2013), em sua tese de doutorado intitulada "Dilemas da Atuação do Poder Judiciário: ativismo judicial sob a ótica do pensamento de Ronald Dworkin", explica algumas teorias relativas ao fenômeno da judicialização das relações sociais, quais sejam: evolucionistas, funcionalistas, modelo econômico-institucional e tese da preservação da hegemonia política.

(...) Os evolucionistas veem o processo de judicialização das relações sociais como inevitável, sendo explicado por fatores endógenos. (...) Para essa teoria, o fenômeno da judicialização das relações sociais decorre da própria evolução das instituições políticas que passa a adotar um modelo de funcionamento mais apto para garantir os direitos fundamentais.

A judicialização das relações sociais, na concepção funcionalista, é uma resposta às pressões do próprio sistema político e da estrutura adotada pelas Constituições Modernas. (...) O modelo econômico- institucional é uma abordagem utilitarista que vê o aumento da judicialização como resposta ao problema da estabilização das leis e da credibilidade do regime adotado. (...)

A tese da preservação da hegemonia política afirma que os detentores do poder têm incentivado a judicilização das relações sociais e da política como forma de manter sua hegemonia. (p. 55-57)

Por outro lado, o ativismo já é representado por uma atuação mais intensa do Poder Judiciário no que diz respeito às funções próprias dos Poderes Legislativo e Executivo. Conforme nos ensina BARROSO (2008, p. 04),

\begin{abstract}
A idéia de ativismo judicial está associada a uma participação mais ampla e intensa do Judiciário na concretização dos valores e fins constitucionais, com maior interferência no espaço de atuação dos outros dois Poderes. A postura ativista se manifesta por meio de diferentes condutas, que incluem: (i) a aplicação direta da Constituição a situações não expressamente contempladas em seu texto e independentemente de manifestação do legislador ordinário; (ii) a declaração de inconstitucionalidade de atos normativos emanados do legislador, com base em critérios menos rígidos que os de patente e ostensiva violação da Constituição; (iii) a imposição de condutas ou de abstenções ao Poder Público, notadamente em matéria de políticas públicas.
\end{abstract}

A expressão "ativismo judicial", de acordo com os ensinamentos de SOARES (2010, p. 14) indica que a Corte está deixando de lado a atividade interpretativa, que é sua função precípua, para criar um direito, estabelecendo novas condutas e diretrizes. SOARES (2010) ainda acrescenta que essa expressão indica "um avanço do juiz para além do campo hermenêutico, invadindo esferas de competências de outros poderes, até mesmo com o estabelecimento de novas condutas não previstas na legislação em vigor”.

Ainda, conforme o referido autor (2010, p. 23-26), há 04 justificativas para uma maior intervenção do Poder Judiciário na tomada de decisões políticas e sociais no cenário 
brasileiro: 1- o crescimento das demandas por pronunciamento judicial quanto a essas questões; 2- descrédito do Poder Legislativo pela sociedade; 3- o fato de que o ativismo possibilita que a sociedade exerça um maior controle da ética na política; 4- a própria vontade dos juízes em decidir questões políticas.

Vale ressaltar que as duas primeiras justificativas se referem justamente ao enfraquecimento de algumas instituições democráticas. Diante disso, é possível constatar que a sociedade possui uma desconfiança muito grande no que diz respeito à concretização de direitos sociais por parte dos Poderes Legislativo e Executivo. A morosidade da atividade legiferante, a omissão do Poder Legislativo quanto à positivação de direitos e garantias fundamentais, bem como a ineficiência do Poder Público em efetivar políticas públicas e resolver problemas políticos são os principais fatores que levam a sociedade brasileira a buscar soluções no âmbito judicial.

Atualmente, um papel ativista do Judiciário encontra um terreno bastante fértil no Brasil. Em época de "Lava-Jato", principalmente, vê-se o envolvimento de diversos agentes políticos, seja do Poder Executivo ou do Poder Legislativo, em escândalos que causaram, e ainda causam, um rombo aos cofres públicos. Diante desse cenário, impossível não constatar uma esperança da sociedade em relação ao Poder Judiciário, face à necessidade de se buscar justiça e acabar com a corrupção no país.

Resumindo, o objetivo do ativismo judicial consiste em fazer valer a Constituição do país, fazendo prevalecer a sua versão desta, porém, invadindo a competência reservada aos demais poderes, sanando determinada omissão legislativa ou executando políticas públicas contrárias à determinação do Executivo (BECATTINI, 2013, p. 58).

Vale fazer uma reflexão quanto ao papel do STF no que diz respeito a essas decisões voltadas à efetivação de direitos fundamentais garantidos pela nossa Magna Carta. É claro que uma atuação moderada do Judiciário, no que diz respeito, principalmente, à efetivação de direitos fundamentais, é muito bem vinda. O problema é o Poder Judiciário se utilizar do ativismo como forma de acalmar os anseios de uma sociedade, com a utilização desse poder maior para fins retóricos.

\subsection{Divergência sobre uma postura ativista ou não do Judiciário Brasileiro quanto à utilização do ECI}

CAMPOS (2015, p. 07), em sua tese apresentada como requisito parcial para a obtenção de título de Doutor, sob a orientação de Daniel Sarmento, defendeu a ideia de que " $o$ 
sistema carcerário brasileiro é exemplo de um estado de coisas inconstitucional que requer intervenção judicial da espécie". Ademais, acrescentou acerca da legitimidade da adoção de tal teoria "se presentes os pressupostos próprios do estado de coisas inconstitucional e o Tribunal formular decisões flexíveis, determinando a formulação e implementação de políticas públicas, mas deixando aos poderes políticos a tarefa de definir o conteúdo e os meios dessas políticas".

Por outro lado, há autores, como STRECK (2015), que demonstram certa preocupação na aplicação da tese do estado de coisas inconstitucional no Brasil. O citado professor teme que "com o tempo, a simples evocação do ECI seja motivo para que se reconheça qualquer tipo de demanda por inconstitucionalidade ao Judiciário". Isto é, uma das grandes preocupações quanto a aplicação da ECI é a banalização que esta pode ocasionar, de forma que o STF possa resolver aplicar tal teoria a todo e qualquer caso que aparecer.

Um ponto interessante trabalhado por STRECK (2015) é referente ao objeto analisado na tese do "estado de coisas inconstitucional". Sua crítica é em relação à maneira como a noção de ECI foi e está sendo construída no ordenamento jurídico brasileiro. Isso porque " $O$ objeto do controle de constitucionalidade são normas jurídicas, e não a realidade empíricavista de forma cindida- sob a qual elas incidem". Dessa forma, entende-se que o ponto crítico abordado pelo referido autor remonta à problemática questão da utilização de argumentos de políticas e argumentos de princípios, análise esta feita precipuamente por Dworkin.

DWORKIN (2011, p. 129) faz a seguinte distinção entre argumentos de política e argumentos de princípios:

(...) Os argumentos de política justificam uma decisão política, mostrando que a decisão fomenta ou protege algum objetivo coletivo da comunidade como um todo. (...) os argumentos de princípio justificam uma decisão política, mostrando que a decisão respeita ou garante um direito de um indivíduo ou de um grupo.

Em continuidade a este raciocínio, DWORKIN (2011, p. 141) acrescenta que "os argumentos de princípio são argumentos destinados a estabelecer um direito individual; os argumentos de política são argumentos destinados a estabelecer um objetivo coletivo".

CRUZ (2007, p. 257) faz uma crítica quanto à utilização desses argumentos de política:

Ora, já vimos que os direitos não acatam a lógica da preferência, eis que gradual e utilitarista. Quando se toma por base a Constituição como uma tábua de valores, os juízes passam a sentir legitimados a 'legislar', a assumir o lugar do executivo, porque se sentem eleitos por Deus ou entendem que têm uma condição moral 
diferenciada dos 'corruptos dos outros Poderes'. E acabam se esquecendo de que com isso colocam em risco a própria democracia.

O referido professor ainda acrescenta sua crítica quanto ao ativismo judicial:

\begin{abstract}
"O ativismo judicial não se dá em torno da dimensão criacional da interpretação. $\mathrm{O}$ 'ativismo' no bojo da teoria discursiva se caracteriza no instante em que o julgador arroga a si o direito de ponderar fins e meios de forma utilitarista, com emprego de argumentos pragmáticos, isso é, por meio de argumentos de política" (2007, p. 266)
\end{abstract}

Nessa linha de raciocínio, KOZICKI (2012, p. 36) também aponta críticas à utilização desses argumentos de política, senão vejamos:

\begin{abstract}
Os argumentos de política, conforme mencionados acima, se prestam à justificação de decisões políticas, enquanto decisões judiciais devem ser sempre justificadas por argumentos de princípios. Os princípios se constituiriam muito mais em diretrizes para as decisões judiciais do que em mera aplicação das regras existentes de direito. Seriam precisamente esses princípios, que devem ser buscados na história institucional da sociedade, que permitiriam afastar a ideia de discricionariedade judicial.
\end{abstract}

Por fim, quanto à preocupação acerca da utilização banalizada da "teoria do estado de coisas inconstitucional", DE GIORGI (2015) ainda complementa o pensamento exteriorizado por Streck, ao se perguntar se as referidas "falhas estruturais" podem realmente ser corrigidas por meio de sentenças judiciais.

Sob o pretexto de dar eficácia aos direitos fundamentais, o Estado de Coisas Inconstitucional os ameaça. Num país marcado pelos sem-teto, sem-saúde, semeducação e sem-segurança, o conceito de ECI despreza o fato de que o sistema jurídico não tem estruturas, meios e organizações que lhe permitam corrigir essas mazelas por sentenças judiciais (2015).

O professor JÚNIOR (2016), em seu artigo intitulado "Estado de Coisas Inconstitucional" reconhece que a utilização do ECI pressupõe uma atuação ativista por parte do Judiciário, uma vez que "as decisões judiciais vão induvidosamente interferir nas funções executivas e legislativas, com repercussões, sobretudo, orçamentárias". Muitos operadores do Direito, inclusive, defendem que um dos problemas relacionados à utilização do Estado de Coisas Inconstitucional com relação à situação precária dos presídios brasileiros é referente à reserva do possível.

A reserva do possível representa a possibilidade de atuação do Poder Público em conformidade com o que se encontra disponível nos cofres públicos. Em outras palavras, 
condiciona-se a prestação positiva do Estado à (in)existência de recursos públicos. Isto quer dizer que a efetivação de direitos fundamentais, como por exemplo o direito à vida e à integridade física dos apenados, encontra limite no que esteja disponível financeiramente para e/ou pelo Estado.

Contudo, apesar de existir o problema da reserva do possível, esta não pode servir de justificativa para a inércia estatal, no que diz respeito ao comprometimento com as condições mínimas e necessárias a uma existência digna. Dessa forma, a utilização irracional e irrazoável desse argumento por qualquer das funções do Estado -Executivo e Legislativopoderá acarretar a intervenção do Poder Judiciário. Entretanto, essa intervenção só deve acontecer de maneira limitada para que não seja considerada ativismo judicial.

A crítica que se faz quanto ao fato do Judiciário intervir nessas questões orçamentárias é de que nada adianta este poder determinar que o Executivo aja dessa ou daquela maneira e peça que o dinheiro seja gasto de determinado jeito, se os pedidos não se encontram em consonância com o que é disposto financeiramente pelo Estado. É importante reconhecer que os gastos referentes ao melhoramento do sistema penitenciário brasileiro são extremamente exacerbados. CONTI (2015), em seu artigo publicado no Conjur, intitulado "Solução para a crise carcerária tem significativo reflexo orçamentário" explica esse problema da seguinte maneira:

\footnotetext{
A administração do sistema prisional coloca à prova a capacidade de o Estado fazer valer a Constituição, uma vez que nela está expresso, entre os direitos e garantias fundamentais, que "é assegurado aos presos o respeito à integridade física e moral" (Constituição, artigo $5^{\circ}$, XLIX), além de impedir penas cruéis (artigo $5^{\circ}$, XLVII) e estabelecer que a pena seja cumprida em estabelecimentos distintos, de acordo com a natureza do delito, idade e sexo do apenado (artigo $5^{\circ}$, XLVIII), entre outros.
}

Certo é que, diante da inércia do Poder Público em relação à efetivação de direitos e garantias fundamentais constitucionalmente previstos no ordenamento jurídico brasileiro, defende-se sim a atuação do Judiciário como forma de suprir algumas lacunas existentes. Contudo, essa intervenção deve ser limitada, de forma a não ferir o princípio da separação dos poderes ou até mesmo colocar em risco a legitimidade democrática. Evidencia-se, portanto, que a atuação do Judiciário brasileiro nem sempre deve ser vista de maneira negativa, uma vez que há uma necessidade de intervenção diante da não atuação dos outros poderes em suas funções precípuas, principalmente no que diz respeito à efetivação de direitos sociais. É 
importante salientar que diversas decisões importantes foram proferidas pelo Poder Judiciário diante da inércia dos demais poderes.

Foi a partir de decisões do Supremo Tribunal Federal e não de leis votadas pelo Congresso Nacional que o cigarro foi proibido em avião, a pesquisa com célulastronco foi liberada, a proibição ao nepotismo foi estendida aos Três Poderes, a distribuição do coquetel contra o vírus da Aids fez-se gratuita, a demarcação de reservas indígenas ganhou novas regras, os servidores públicos tiveram garantido o direito de fazer greve e os partidos tornaram-se detentores dos mandatos de seus eleitos (FERREIRA, 2015).

Dessa forma, vê-se que a utilização do argumento da reserva do possível como forma de impedir a intervenção do Judiciário da problemática questão sobre a situação atual dos presídios brasileiros deve ser feita com bastante cautela. Contudo, não se pode deixar de lado que se houver negligência dos Poderes Legislativo e Executivo na efetivação de direitos fundamentais aos presos, o Poder Judiciário estará legitimado a intervir nesta questão.

\subsection{Por que devemos nos preocupar com o ativismo judicial no Brasil?}

Apesar de ser necessária uma intervenção do Judiciário quanto às questões sociais, principalmente no que diz respeito a uma posição passiva dos Poderes Executivo e Legislativo na garantia de direitos fundamentais aos cidadãos, essas intervenções devem ser analisadas no caso concreto. Isso porque, há decisões em que a intervenção do Judiciário realmente é legítima, porém há intervenções extremamente abusivas, que acabam por colocar em risco a legitimidade democrática da atuação dos Magistrados.

No ano de 2016, o Supremo Tribunal Federal se utilizou, de forma absurda, da função ativista, deixando de exercer sua atividade interpretativa para, literalmente, criar um direito novo, desafiando a própria Magna Carta. No dia 17 de fevereiro do referido ano, o Supremo Tribunal Federal deu uma reviravolta em sua Jurisprudência, firmada desde 2009, e desafiou a Constituição Republicana de 1988 ao julgar o HC 126.292/SP ${ }^{3}$.

Neste julgamento, a Corte Suprema Brasileira firmou o entendimento de que seria possível o cumprimento da pena em caráter provisório, mesmo que, ainda, não tenha ocorrido o trânsito em julgado da decisão condenatória. O Relator do julgamento, Ministro Teori Zavascki, iniciou a mudança de entendimento do STF com as seguintes palavras:

\footnotetext{
${ }^{3}$ Vale ressaltar que este entendimento foi ratificado novamente em outubro de 2016, a partir do julgamento das liminares das Ações Declaratórias de Inconstitucionalidade n. 43 e 44, defendendo que o artigo 283 do CPP não impede o início da execução da pena após condenação em segunda instância.
} 
(...) O tema relacionado com a execução provisória de sentenças penais condenatórias envolve reflexão sobre (a) o alcance do princípio da presunção da inocência aliado à (b) busca de um necessário equilíbrio entre esse princípio e a efetividade da função jurisdicional penal, que deve atender a valores caros não apenas aos acusados, mas também à sociedade, diante da realidade de nosso intricado e complexo sistema de justiça criminal.

(...) Ressalvada a estreita via da revisão criminal, é, portanto, no âmbito das instâncias ordinárias que se exaure a possibilidade de exame de fatos e provas e, sob esse aspecto, a própria fixação da responsabilidade criminal do acusado. É dizer: os recursos de natureza extraordinária não configuram desdobramentos do duplo grau de jurisdição, porquanto não são recursos de ampla devolutividade, já que não se prestam ao debate da matéria fática probatória.

(...) Nessas circunstâncias, tendo havido, sem segundo grau, um juízo de incriminação do acusado, fundado em fatos e provas insuscetíveis de reexame pela instância extraordinária, parece inteiramente justificável a relativizacão e até mesmo a própria inversão, para o caso concreto, do princípio da presuncão de inocência até então observado.

Para 07 ministros, à época, Teori Zavascki, Luís Roberto Barroso, Dias Toffoli, Luiz Fux, Edson Fachin, Carmen Lúcia e Gilmar Mendes, tal cumprimento não ofenderia o princípio constitucional da presunção de inocência. Isso porque, como os recursos extraordinários não se prestam a discutir matéria fática, mas tão somente questões de direito, a execução já não ofenderia a presunção, pois a decisão de $2^{\circ}$ grau já teria considerado o indivíduo culpado. Ademais, o Relator ainda acrescentou que os recursos extraordinários (especial e extraordinário) não são dotados de efeito suspensivo, interpretação esta realizada com base na conjunção dos artigos 637 do Código de Processo Penal e o art. 27, §² $2^{\circ}$ da Lei $8038 / 90$

Esse julgamento foi histórico, uma vez que modificou um entendimento adotado pela Suprema Corte Brasileira desde o ano de 2009. No dia 05 de fevereiro de 2009, por 7 votos a 4, o STF havia decidido que uma pessoa acusada da prática de um delito só poderia ser presa após o trânsito em julgado, em claro respeito ao princípio da presunção de inocência.

Naquele caso, ocorreu o julgamento do HC 84.078/MG, em que configurava como paciente Omar Coelho Vitor, denunciado e condenado pelo crime previsto no art. $121, \S 2^{\circ}$, incisos I e IV, c/c art. 14, inciso II, todos do Código Penal, à pena de 03 anos e 06 meses de reclusão. Após apelação do Ministério Público e, consequentemente, após um novo Júri, o autor foi condenado a 07 anos e 06 meses, a serem cumpridos em regime inicialmente fechado. Antes da admissão do Recurso Especial interposto pela defesa, o Ministério Público pugnou pela prisão preventiva, a qual foi decretada pelo Tribunal de Minas Gerais, sendo esta mantida pelo Superior Tribunal de Justiça. 
No julgamento do referido Habeas Corpus, o até então relator, Ministro Eros Grau, concedeu o citado writ, nos seguintes fundamentos:

(...) Afastado o fundamento da prisão preventiva, o encarceramento do paciente após o julgamento do recurso de apelação ganha contornos de execução antecipada da pena.(...) Refletindo a propósito da matéria, estou inteiramente convicto de que o entendimento até agora adotado pelo Supremo deve ser revisto.

(...) Ora, se é vedada a execução da pena restritiva de direito antes do trânsito em julgado da sentença, com maior razão há de ser coibida a execução da pena privativa de liberdade- indubitavelmente mais grave- enquanto não sobrevier título condenatório definitivo. Entendimento diverso importaria franca afronta ao disposto no art. $5^{\circ}$, inciso LVII, da Constituicão, além de implicar a aplicação de tratamento desigual a situações iguais, o que acarreta violação ao princípio da isonomia. (...) Aliás, a nada se prestaria a Constituicão se esta Corte admitisse que alguém viesse a ser considerado culpado- e ser culpado equivale a suportar a execucão imediata da pena- anteriormente ao trânsito em julgado de sentenca penal condenatória.

(...) Concedo a ordem para determinar que o paciente aguarde em liberdade o trânsito em julgado da sentença condenatória. (grifos nossos)

Após este julgamento, ficou então decidido que o acusado, antes do trânsito em julgado, só poderia ser preso cautelarmente, ou seja, nos casos de flagrante, preventiva ou de prisão temporária, em claro respeito ao art. 283, caput, do Código de Processo Penal (“Ninguém poderá ser preso senão em flagrante delito ou por ordem escrita e fundamentada da autoridade judiciária competente, em decorrência de sentença condenatória transitada em julgado ou, no curso da investigação ou do processo, em virtude de prisão temporária ou prisão preventiva"). Isto é, nenhuma pessoa poderia cumprir uma pena definitiva de forma antecipada, o que era permitido pelo Supremo até o ano de 2009.

No voto do Ministro Eros Grau, em 2009, o mesmo afirmou que "a antecipação da execução penal, ademais de incompatível com o texto da Constituição, apenas poderia ser justificada em nome da conveniência dos magistrados, não do processo penal" (p. 14). Isso porque, uma eventual antecipação da pena poderia acarretar a redução de recursos a serem apreciados pelas instâncias superiores.

Por isso, a afirmação do Ministro Eros Grau no sentido de que uma decisão nesse sentido, qual seja, a de possibilitar o cumprimento provisório da pena, seria em prol, unicamente, da conveniência dos Magistrados. Ao prestigiar o princípio da presunção de inocência, as instâncias superiores acabariam sendo inundadas pelos recursos extraordinários. Contudo, como bem afirmou Eros Grau naquele seu voto, " $a$ comodidade, a melhor operacionalidade de funcionamento desta Corte não pode ser lograda a esse preço" (p. 14). 
Certo é que, em 07/11/2019, o Plenário do Supremo Tribunal Federal, ao julgar o mérito das Ações Declaratórias de Constitucionalidade n 43, 44 e 54, de relatoria do Ministro Marco Aurélio, mais uma vez reformulou a sua jurisprudência, decidindo que o cumprimento da pena somente pode ter início com o esgotamento de todos os recursos. Restou definido no referido julgamento que a única possibilidade de prisão após decisão em segunda instância é aquela decorrente do preenchimento dos requisitos para a prisão preventiva previstos no artigo 312 do Código de Processo Penal, não sendo possível a execução provisória da pena.

Portanto, viu-se que o Plenário do STF já modificou o seu posicionamento por diversas vezes, de forma que não podemos afirmar com convicção se o atual entendimento (de não ser possível a execução provisória) irá prevalecer por muito tempo.

Dessa forma, é possível constatar, não só a partir dessas decisões históricas, mas também de outras, que há uma grande discricionariedade por parte do Poder Judiciário Brasileiro, em especial o STF. Quando se tem uma interpretação vindo da própria consciência do Magistrado, vê-se decisões completamente divergentes dos preceitos constitucionais. STRECK (2013, p. 95) afirma a sua indignação perante este papel ativista do Judiciário, criticando o chamado solipsismo judicial, que nada mais é do que a possibilidade de tomada de decisões a partir de critérios pessoais.

Na verdade, o "drama" da discricionariedade que critico reside no fato de que
esta transforma os juízes em legisladores. E, para além disso, esse "poder
discricionário" propicia a "criação" do próprio objeto de "conhecimento", típica
manifestação do positivismo. Ou seja, a razão humana passa a ser a "fonte
iluminadora" do significado de tudo o que pode ser enunciado sobre a
realidade. As coisas são reduzidas aos nossos conceitos e às nossas concepcões
de mundo, ficando à dis-posição de um protagonista (intérprete lato sensu).
Consequências disso? Inúmeras.

O que se vê, a partir da leitura do voto do Ministro Teori Zavascki, em 2016, é justamente essa atitude solipsista, já que, para ele, a execução provisória da pena era de suma importância para o combate à criminalidade e, consequentemente, para acalmar os ânimos de uma sociedade agoniada pela impunidade. Isto é, colocou-se um juízo de valor em cima de um julgamento, que, contudo, produziu um resultado extremamente absurdo que representou um grande retrocesso do Poder Judiciário quanto à efetivação do tão sonhado Estado Democrático de Direito.

É fato notório e incontroverso que inúmeras foram as consequências decorrentes daquele julgamento histórico do STF em 2016 quanto a possibilidade de execução provisória da pena. Uma delas, a principal, foi a continuidade do processo de superlotação das prisões 
brasileiras, o que vai na direção contrária aos argumentos utilizados pelo Supremo Tribunal no que diz respeito à ADI 347, em que discute a tese do "estado de coisas inconstitucional" e a necessidade de desafogamento das prisões brasileiras.

Ademais, como bem já explanou MAUS (2000, p. 14), citando Weber, “o juiz torna-se o próprio juiz da lei- a qual é reduzida a 'produto e meio técnico de um compromisso de interesses'-, investindo-se como sacerdote-mor de uma nova 'divindade': a do direito suprapositivo e não escrito". Contextualizando, Maus fez uma dura crítica ao TFC (Tribunal Federal Constitucional da Alemanha), crítica esta que serve como uma luva ao nosso Supremo Tribunal Federal após a decisão proferida no dia 17 de fevereiro de 2016.

A autora fez em sua obra uma reflexão sobre a competência do TFC e concluiu que o mesmo estabelecia princípios de direito suprapositivos a partir de sua atividade constitucional de controle normativo, o que acabava por influenciar na criação de uma "Justiça de Gabinete" (MAUS, 2000, p. 12). Dessa forma, o Judiciário decidia conforme teses próprias, passando por cima, inclusive, de preceitos constitucionais.

Essa visão cabe perfeitamente à realidade jurisdicional brasileira. Isso porque o Poder Judiciário, em especial o Supremo Tribunal Federal, acaba se colocando como a maior instituição moral existente na sociedade, afirmando que as suas decisões representam a justiça, sendo que, contudo, por muitas vezes, revelam uma postura retrógrada numa sociedade qualificada, em tese, como democrática.

\footnotetext{
Quando a Justiça ascende ela própria à condição de mais alta instância moral da sociedade, passa a escapar de qualquer mecanismo de controle social controle ao qual normalmente se deve subordinar toda instituicãa do Estado em uma forma de organização política democrática. No domínio de uma Justiça que contrapõe um direito "superior", dotado de atributos morais, ao simples direito dos outros poderes do Estado e da sociedade, é notória a regressão a valores prédemocráticos de parâmetros de integração social. (MAUS, 2000, p. 05- grifo nosso)
}

Portanto, o julgamento do HC 126.292/SP, no ano de 2016, entrou para a história pela decisão do Plenário do STF ter sido extremamente polêmica e, de certa forma, contraditória a outros argumentos utilizados pelo próprio Tribunal. Entretanto, será lembrado como um grave retrocesso do Poder Judiciário Brasileiro frente a uma era de efetivação de direitos e garantias fundamentais. O que se observou, àquela época, nas palavras do advogado Pedro Estevam Serrano (2016), foi a outorga de "uma nova Norma Constitucional de forma originária. Suprimiu direito pétreo que deveria ser imutável". Ainda acrescentou que tal postura, 
extremamente autoritária e discricionária da Suprema Corte, tratou-se de "um imenso vilipêndio à democracia e ao estado de direito, inaceitável e que deve ser combatido".

Por isso, diante dessa e de tantas outras tantas decisões proferidas pelo Supremo Tribunal Federal, que revelam um ativismo até mesmo exagerado, no sentido de interpretações absurdas da Constituição da República, entende-se que deve haver sim uma certa limitação do Poder Judiciário na sua atuação.

\section{CONCLUSÃO}

Com o presente trabalho pretendeu-se realizar uma análise da atuação do Poder Judiciário nos dias atuais a partir de uma decisão, ainda em caráter liminar, sobre a condição do sistema penitenciário brasileiro.

No caso da Arguição de Descumprimento de Preceito Fundamental no 347, ajuizada pelo Partido Socialismo e Liberdade-PSOL, discute-se a possibilidade de utilização da "teoria do estado de coisas inconstitucional" no que se refere ao reconhecimento da falência do sistema prisional no Brasil. Diante da insalubridade, das péssimas condições de cumprimento de pena, vê-se a necessidade de adoção de políticas que possibilitem uma ressocialização do apenado no país.

Dessa forma, viu-se que, diante da ineficiência do Poder Executivo e da morosidade do Poder Legislativo, é totalmente compreensível e democrática uma intervenção do Poder Judiciário na efetivação de direitos e garantias fundamentais relativos à população.

Contudo, mesmo defendendo uma intervenção do Poder Judiciário quanto à efetivação de direitos e garantias fundamentais, principalmente pela posição passiva dos demais poderes na garantia daqueles direitos e garantias, essas intervenções devem ser analisadas caso a caso. Isso porque, ao mesmo tempo em que há decisões realmente legítimas, em completa conformidade com a Constituição da República, há atuações extremamente abusivas, que acabam por colocar em risco a legitimidade democrática da atuação dos Magistrados.

O caso o qual considero mais emblemático foi o julgamento do HC 126.292/SP em 2016. Neste caso, o Supremo Tribunal Federal firmou o entendimento de que seria possível o cumprimento da pena em caráter provisório, mesmo sem o trânsito em julgado da decisão, desde que prolatado o acórdão condenatório em segunda instância. Dessa forma, a Corte Suprema Brasileira utilizou-se, de forma completamente ilegítima, da função ativista, 
deixando de exercer sua atividade interpretativa para, literalmente, criar um "direito" novo, desafiando a própria Constituição Federal.

Portanto, defende-se o entendimento de que o Poder Judiciário deve adotar uma postura intermediária entre o ativismo e a moderação judicial. Isto é, o Judiciário não pode ter uma atuação excessiva em relação a questões que não estão dispostas no texto constitucional como de sua competência, porém não pode permanecer inerte em caso de não atuação dos demais poderes, principalmente em casos que envolvem questões relacionadas aos direitos fundamentais dos cidadãos.

\section{REFERÊNCIAS}

ADPF No 347. Disponível em: https://www.conjur.com.br/dl/psol-stf-intervenha-sistemacarcerario.pdf. Acesso em: 17 jun 2016.

BARROSO, Luis Roberto. Judicialização, ativismo judicial e legitimidade democrática. Revista Consultor Jurídico. 22 de dezembro de 2008. Disponível em:

https://www.conjur.com.br/2008-dez-

22/judicializacao_ativismo_legitimidade_democratica?pagina=2. Acesso em: 04 jan. 2016.

BECATTINI, Sérgio Rubens Birchal. Dilemas da Atuação do Poder Judiciário: ativismo judicial sob a ótica do pensamento de Ronald Dworkin. Belo Horizonte: D’Plácido Editora, 2013.

BRASIL, Ministério da Justiça. Levantamento Nacional de Informações Penitenciárias InfoPen- Junho de 2014. Disponível em: http://www.justica.gov.br/seus-direitos/politicapenal/transparencia-institucional/estatisticas-prisional/levantamento-nacional-de-informacoespenitenciarias. Acesso em: $17 \mathrm{fev}$. de 2016.

BRASIL. Congresso Nacional. Câmara dos Deputados. Comissão Parlamentar de Inquérito do Sistema Carcerário. Disponível em: https://bd.camara.leg.br/bd/handle/bdcamara/2701. Acesso em: 25 março 2016.

BRASIL. Presidência do Brasil. Mapa do Encarceramento: os jovens do Brasil. Brasília, 2015. Disponível em: www.pnud.org.br/arquivos/encarceramento_WEB.pdf. Acesso em: 02 de jan. 2016.

CAMPOS, Carlos Alexandre de Azevedo. Da Inconstitucionalidade por Omissão ao "Estado de Coisas Inconstitucional”. 2015. Tese de Doutorado em Direito Público. Faculdade de Direito - Universidade do Estado do Rio de Janeiro. 
CANÁRIO, Pedro. Leia o voto de Teori Zavascki sobre prisão de condenado em segundo grau. Revista Consultor Jurídico. 17 de fevereiro de 2016. Disponível em:

https://www.conjur.com.br/2016-fev-17/leia-voto-relator-prisao-condenado-segundo-grau.

Acesso em: 28 jul. 2016.

CARVALHAL, Ana Paula. Corte Interamericana decide pela vinculação de sua jurisprudência. Revista Consultor Jurídico. Disponível em:

https://www.conjur.com.br/2014-set-27/observatorio-constitucional-corte-interamericanadecide-vinculacao-jurisprudencia. Acesso em: 15 de jan. de 2016.

CONTI, José Maurício. Solução para a crise carcerária tem significativo reflexo orçamentário. Revista Consultor Jurídico. 5 de agosto de 2015. Disponível em: https://www.conjur.com.br/2015-ago-25/contas-vista-solucao-situacao-carcerariasignificativos-reflexos-orcamentarios. Acesso em 04 jan de 2016.

CRUZ, Álvaro Ricardo de Souza. Hermenêutica e(m) debate: o constitucionalismo brasileiro entre a teoria do discurso e a ontologia existencial. Belo Horizonte: Fórum, 2007.

DE GIORGI, Raffaele; FARIA, José Eduardo; CAMPILONGO, Celso. Opinião: Estado de coisas inconstitucional. Estadão, São Paulo, 19 set 2015. Disponível em:

https://opiniao.estadao.com.br/noticias/geral,estado-de-coisas-inconstitucional,10000000043. Acesso em: 18 fev. 2016.

DWORKIN, Ronald. Levando os direitos a sério. Tradução: Nelson Boeira. $3^{\circ}$ ed. São Paulo: Editora WMF Martins Fontes, 2011.

FERREIRA, Eduardo Oliveira. Ativismo judicial: aspectos históricos da nova tendência do judiciário. Disponível em: https://pt.scribd.com/document/51811016/Ativismo-Judicial. Acesso em: 10 fev. 2016.

GUSTIN, Miracy Barbosa de Sousa. (Re)pensando a pesquisa jurídica: teoria e prática. $4^{\mathrm{a}}$ ed. Belo Horizonte: Del Rey, 2013.

JOTA. O voto de Teori Zavascki no HC 126.292, que mudou jurisprudência do STF sobre execução de pena. Disponível em: https://www.jota.info/o-voto-de-teori-zavascki-nohc-126-292-que-mudou-jurisprudencia-do-stf-sobre-execucao-de-pena. Acesso em: 18 fev. de 2016.

KOZICKI, Katya. Levando a justiça a sério: interpretação do direito e responsabilidade judicial. Belo Horizonte: Editora Arraes, 2012.

MAUS, Ingborg. Judiciário como Superego da Sociedade: o papel da atividade jurisprudencial na "sociedade órfã". Novos Estudos - CEBRAP. N. ${ }^{\circ}$ 58, novembro 2000, p. 183-202.

OST, François. Júpiter, Hércules, Hermes: Tres modelos de juez. Trad. Isabel Lifante Vidal. In DOXA - Cuadernos de Filosofia, número 14, 1993, p. 188. Disponível em: 
http://bib.cervantesvirtual.com/servlet/SirveObras/public/01360629872570728587891/cuader no14/doxa14_11.pdf?portal=4. Acesso em: $28 \mathrm{dez} .2015$.

PONTIFÍCIA UNIVERSIDADE CATÓLICA DE MINAS GERAIS. Pró-Reitoria de Graduação. Sistema de Bibliotecas. Padrão PUC Minas de normalização: normas da ABNT para apresentação de teses, dissertações, monografias e trabalhos acadêmicos. 9. ed. rev. ampl. atual. Belo Horizonte: PUC Minas, 2011. Disponível em:

http://www.pucminas.br/ biblioteca. Acesso em: 04 jan. 2016.

RONCAGLIA, Daniel. É proibida execução de pena antes do fim do processo. Disponível em: http://www.conjur.com.br/2009-fev-05/prisao-feita-processo-transitado-julgado-stf.

Acesso em: 17 fev. 2016.

SENTENCIA T-153/98. Disponível em:

https://www.corteconstitucional.gov.co/relatoria/1998/t-153-98.htm. Acesso em: 06/04/2016.

SERRANO, Pedro Estevam. O erro supremo. 19 fev. 2016. Justificando. Disponível em: http://justificando.com/2016/02/19/o-erro-supremo/. Acesso em: 19 fev. 2016.

SOARES, José Ribamar Barreiro. Ativismo Judicial no Brasil: O Supremo Tribunal Federal como arena de deliberação política. Tese apresentada como requisito parcial para obtenção do título de Doutor, ao Programa de Pós-Graduação em Ciência Política, do Instituto de Estudos Sociais e Políticos (IESP) - UERJ, 2010. Disponível em: www.bd.camara.gov.br/bd/bitstream/handle/.../ativismo_judicial_soares.pdf. Acesso em: 01 março de 2016.

STRECK, Lênio Luiz. O que é isto- decido conforme minha consciência? $4^{\circ}$ Ed. rev. Porto Alegre: Livraria do Advogado Editora: 2013. 